\title{
Phytobenthic Assemblages of Addaia Bay (Menorca, Western Mediterranean): Composition and Distribution
}

\author{
G. Ribera ${ }^{a}$, M. Coloreu ${ }^{a}$, C. Rodríguez-Prieto ${ }^{b}$ and E. Ballesteros ${ }^{a, *}$ \\ ${ }^{a}$ Centre d'Estudis Avançats de Blanes - CSIC. C. Sta Bàrbara s/n, E-17300 Blanes, Spain \\ b Departament de Ciències Ambientals, Facultat de Ciències Experimentals, Universitat de Girona, Campus de Montilivi \\ s/n, E-17071 Girona, Spain \\ * Corresponding author
}

Addaia Bay is a rather small ( $85 \mathrm{ha}$ ), shallow (less than $12 \mathrm{~m}$ depth) and sheltered bay situated on the northern coast of Menorca (Balearic Islands, western Mediterranean), where the seabed is mostly covered by seagrass meadows. The seagrass Cymodocea nodosa dominates the inner parts of the bay, with densities up to 2325 shoots $\mathrm{m}^{-2}$, while Posidonia oceanica covers most of the outer part, with shoot densities ranging from 235 shoots $\mathrm{m}^{-2}$ in deep waters to 950 shoots $\mathrm{m}^{-2}$ at a depth of $2.5 \mathrm{~m}$. Other widespread phytobenthic communities are dominated by Caulerpa prolifera (muddy bottoms), photophilic algal stands (rocks and dead Posidonia rhizomes), and Ruppia cirrhosa (very sheltered sites). The presence of a well preserved barrier reef made up of Posidonia oceanica in the eastern part of the bay is noteworthy, since these formations have disappeared or are in regression all over the Mediterranean coasts. The lagoon, situated at the inner side of the Posidonia reef, is covered by dense Cymodocea nodosa stands and free-living algae (Valonia aegagropila, Rytiphloea tinctoria and maërl). The only anthropic disturbances affecting the bay seem to be the construction of a marina and dredging. Considering the biomass values and the surfaces occupied by each community, the total phytobenthic standing crop of Addaia Bay in summer has been estimated as $1220 \mathrm{tdw}(491 \mathrm{tdw}$ if the below ground biomass of Posidonia oceanica is not considered). Seagrasses account for nearly the $95 \%$ of the total biomass. Average primary production has been estimated to be around $530 \mathrm{~g} \mathrm{dw} \mathrm{m}^{-2} \mathrm{y}^{-1}$, which emphasizes the important contribution of these bays to the total productivity of Mediterranean coastal areas and the predominant role played by seagrass meadows in these environments.

\section{Introduction}

Shallow, sheltered bays are some of the most vulnerable benthic ecosystems to anthropic disturbances. In fact, undisturbed sheltered bays are extremely rare in the northwestern Mediterranean, since they have been favourite sites for human settlement from preRoman times and at present they are preferential places for touristic development (Boudouresque et al. 1985).

Seagrass meadows dominate the benthic assemblages of Mediterranean, non-heavily disturbed, sheltered bays. The development and long-term succession of these meadows is well documented (Molinier and Picard 1952, Pérès and Picard 1964, Augier and Boudouresque 1970, Boudouresque and Meinesz 1982) and several studies have been devoted to the description of their structure and productivity (e.g. Bédhomme et al. 1983, Bay 1984, Caye and Meinesz 1985, Pérez and Camp 1986, Pérez and Romero 1991, Terrados and Ros 1992, Pergent-Martini et al. 1994, Marbà et al. 1996).

Nevertheless, little attention has been paid to the cartography of seagrass meadows (Meinesz et al. 1988), although their distribution and extension are of major importance to determine their relative im- portance in the functioning of these bays. The availability of an accurate cartography is also useful for monitoring eventual changes that can be induced by human activities (Colantoni et al. 1982).

In this paper we describe and chart the benthic communities thriving in Addaia Bay, a rather undisturbed sheltered bay situated on the northern coast of Menorca (Balearic Islands). The exceptionally good conservation of the assemblages found in Addaia are important as they may represent most of the benthic communities once widespread in similar habitats throughout the western Mediterranean.

\section{Materials and Methods}

Addaia Bay is a long (2200 m) and narrow (100 to $400 \mathrm{~m}$ ) irregular, small ( $85 \mathrm{ha})$ bay located on Menorca $\left(40^{\circ} 0^{\prime} 0^{\prime \prime} \mathrm{N}, 4^{\circ} 12^{\prime} 0^{\prime \prime} \mathrm{E}\right)$ (Fig. 1). In the early seventies most of the bay was not urbanized except for some country houses and a small fishermen's village (Na Macaret) situated at the outer western part of the bay. In the early eighties $\mathrm{Na}$ Macaret expanded, and a new urbanization and a small (1.6 ha) marina were built on the western part of the bay. Nowadays, $28 \%$ of the coastline has been somehow 


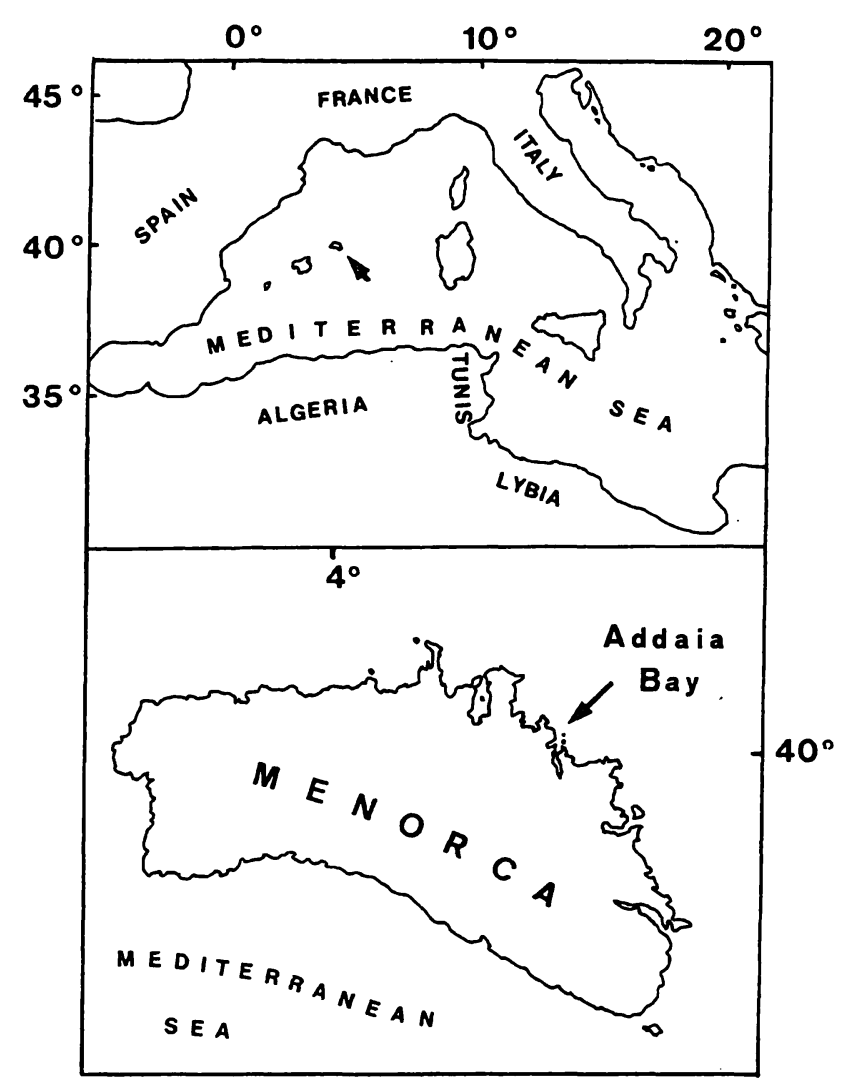

Fig. 1. Location of Addaia Bay.

modified (urbanization, marina), and $15 \%$ is occupied by grassland. Shrub-dominated Mediterranean vegetation covers the rest of the non-modified coastline, with sparse small forests of Tamarix and patches of halophile vegetation (Juncus, Arthrocnemum). Other human impacts include permanent offshore moorings, the occasional anchorages, and the consequences of boat traffic. The watershed is very reduced and no perennial freshwater sources flow into the bay, the innermost part of the bay being occupied by a salt pan.

Aerial photography and diving observations were used to make the chart of Addaia Bay, following methods described in Meinesz et al. (1981), Ramos (1984), Boudouresque et al. (1985) and Meinesz et al. (1988). Bay bathymetry was prepared from a series of echo-sounder transects spaced at 100 meters intervals. An aerial photograph (Flight Par 3, colour shot 9580 , July 1990 , scale $1: 5000$ ) was used to delimit different colour and texture patches. The shoreline and all the boundaries and patches delimited were transferred to a first draft chart. The bathymetric transects were examined by snorkeling or SCUBA diving in September 1995 and the patches identified in the aerial photograph were attributed to benthic communities characterized by dominant species and substrate. Every small patch not crossed by the transects and the inner-bay deep waters, where aerial photographs had no resolution, was accurately scanned by diving. Diving exploration also allowed segregation of different communites (e.g. dead Posi- donia rhizome from photophilic algae on rocky substrate) that were not distinguishable on the photograph. Additional boundaries, not apparent on the photographs, were also traced. This procedure provided a second draft map, which was corrected and improved by several new dives in August 1996 to obtain a final map. Surfaces occupied by each community were estimated after computer preparation of the final map using CANVAS software for Macintosh.

Macroalgal and seagrass biomass were quantified for each community from samples collected in August and September. Shoot density of Posidonia oceanica (L.) Delile was measured at depths of 0.5, $2.5,4.5$ and $9.0 \mathrm{~m}$ by means of 20 quadrats of $20 \mathrm{~cm}$ $\times 20 \mathrm{~cm}$ placed at random in the meadow (Giraud 1977, Boudouresque et al. 1980). Sixteen shoots were collected at each depth and leaf and epiphyte dry biomass ( 48 hours at $70^{\circ} \mathrm{C}$ ) for each shoot was calculated. Above-ground total plant biomass was estimated taking into account density and shoot biomass measures. Sampling on Ruppia cirrhosa, Cymodocea nodosa, Caulerpa prolifera, and rocky photophilic algal communities was performed by collecting from an area of $400 \mathrm{~cm}^{2}$ of seabed using the procedures described in Boudouresque (1971). On soft bottoms, the depth of the sediment collected always exceeded $15 \mathrm{~cm}$, so underground biomass was also removed. The resultant block of macrophytes and sediment was carried up to the surface, cleaned of sediment and detritus, fixed in $4 \%$ formaldehyde : seawater, and sorted in the laboratory. Abundance of each species was quantified as dry biomass (48 hours at $70^{\circ} \mathrm{C}$ ) and the number of shoots of the different seagrass species was counted.

\section{Results}

\section{Cartography}

Addaia Bay has extensive zones of very shallow water situated at the end of three different basins. The central basin is the longest and most of it has a central, relatively deep, channel. The western basin has a similar morphology although being shorter. The eastern basin lacks a central channel and ends up in a shallow, sheltered lagoon (Fig. 2).

Twelve main benthic communities have been considered to draw the final bionomic chart of Addaia Bay (Fig. 3). Six seagrass-dominated communities were distinguished. Pure Posidonia oceanica stands and Posidonia oceanica patches among dead rhizome were the dominant communities at the outer part of the bay, although small areas with Posidonia occurred in the shallows of the inner central and eastern basins. A barrier reef of Posidonia oceanica (Molinier and Picard 1952, Ros et al. 1985) delimited a shallow lagoon at the innermost part of the eastern basin. Cymodocea nodosa meadows (mixed with the green alga Caulerpa prolifera, without Caulerpa, or patchy 
outgrowths between boulders) were dominant at the inner parts of the three basins, at depths ranging from 0 to $4 \mathrm{~m}$. A small Ruppia cirrhosa meadow was found in an extremely sheltered, shallow part of the central basin. Small areas of dead rhizomes of Posidonia oceanica covered by photophilic algae were present in the shoals at the entrance of the bay and close to Na Macaret quay. Stands of Caulerpa prolifera covered some of the muddy bottoms of the central basin, at depths between 2 and 9 meters. Scattered rocks and the areas of rocky coastline, between 0 and 2 meters depth, were covered with photophilic brown and red algae. Littoral muddy bottoms with filamentous blue green algae occurred in a sheltered part of the lagoon of the eastern basin: Muddy bottoms devoid of macrophyte development covered extensive areas in the channels of the western and central basins. Finally, small patches of sandy bottoms were found in the more exposed zones near the shoals at the entrance of the bay, and in the eastern basin.

The total surface covered by each community is summarized in Table I. Cymodocea nodosa meadows occupy $44 \%$ of the bay, while Posidonia oceanica beds, healthy or mixed with dead rhizomes, cover

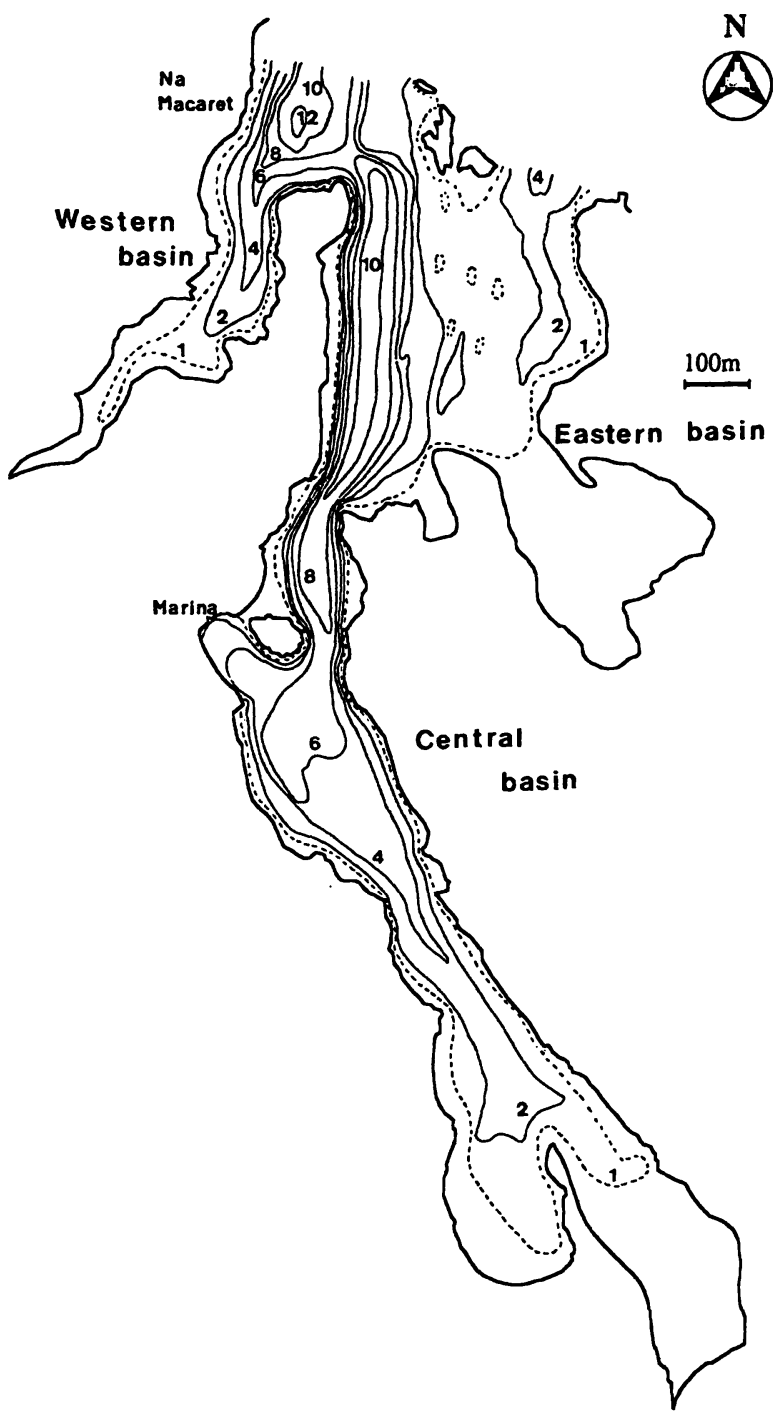

$30 \%$. Therefore, seagrass meadows cover nearly the $75 \%$ of the bay. Muddy bottoms with or without a sparse coverage of Caulerpa prolifera account for a

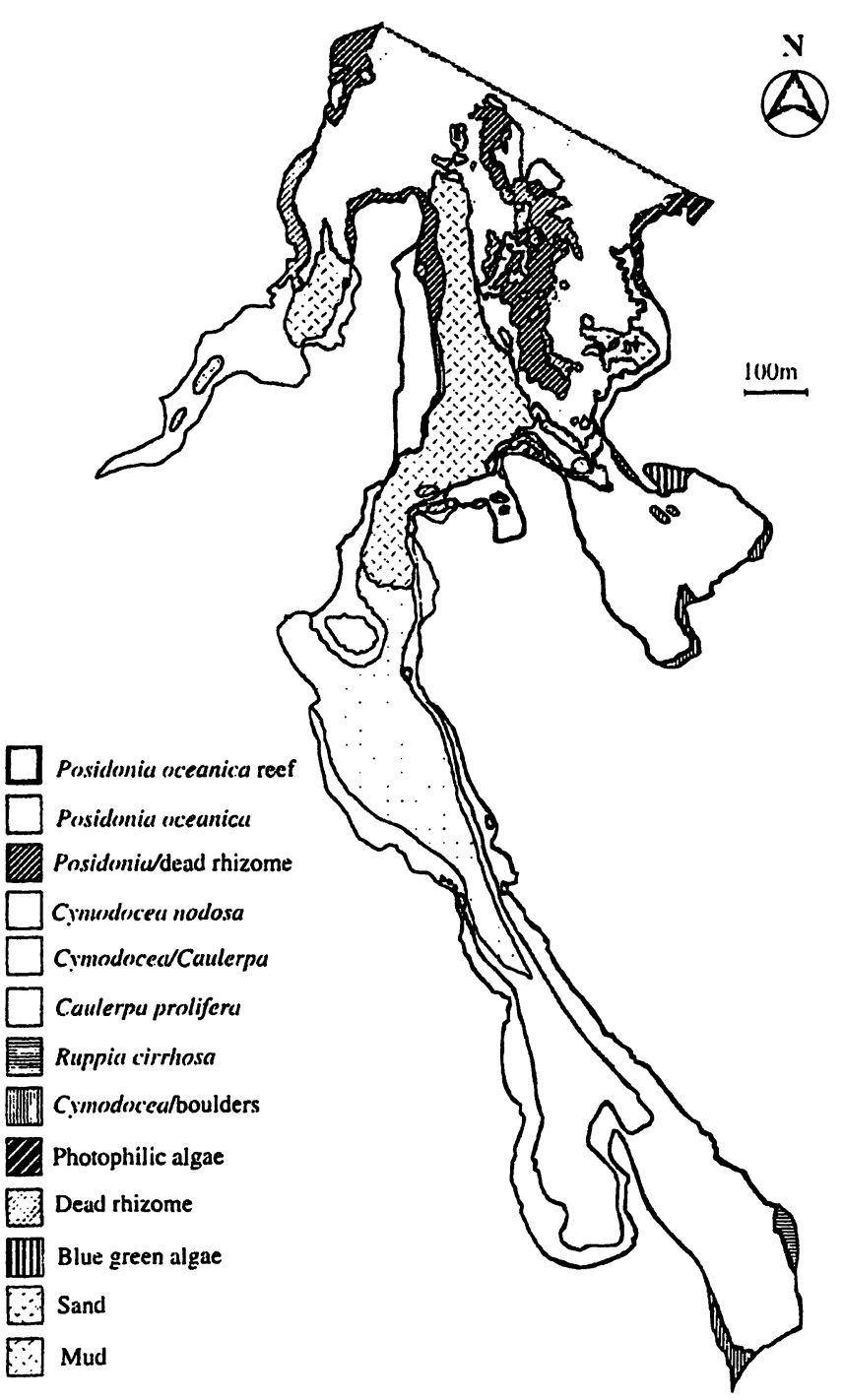

Fig. 3. Cartography of the sea-bottom communities of Addaia Bay.

Table I. Surface area (in ha) occupied by each phytobenthic community distinguished in Addaia Bay and represented in Figure 3.

\begin{tabular}{lc}
\hline Community & Hectares \\
\hline Cymodocea nodosa & 26.84 \\
Posidonia oceanica & 22.61 \\
Cymodocea/Caulerpa & 10.01 \\
Caulerpa prolifera & 8.70 \\
Mud devoid of macrophytes & 8.62 \\
Posidonia/dead rhizome & 2.75 \\
Dead rhizome & 2.55 \\
Sand devoid of macrophytes & 1.17 \\
Photophilic algae & 0.58 \\
Cymodocea/boulders & 0.47 \\
Biue green algae & 0.26 \\
Ruppia cirrhosa & 0.24 \\
\hline Total surface & 84.80 \\
\hline
\end{tabular}

Fig. 2. Bathymetric map of Addaia Bay (depth in meters). 
high $20 \%$, while the other communities only account for the remaining $5 \%$.

\section{Description of communities}

At least three kinds of Posidonia oceanica meadows can be distinguished in Addaia Bay according to their morphological features. The Posidonia barrier reef localized at the end of the eastern basin and the shallow patches of Posidonia thriving in sheltered areas of the central basin have an irregular structure, with raised and sunken parts covered with Posidonia or dead rhizome; their density averages 600 shoots $\mathrm{m}^{-2}$ and leaves are heavily colonized by epiphytes in summer (Table II). Meadows situated at depths ranging from 2 to 12 meters are continuous and patches of sand or dead rhizome are rare; their density ranges from 950 shoots $\mathrm{m}^{-2}$ in shallow waters to 240 shoots $\mathrm{m}^{-2}$ in deep waters; epiphyte biomass is the highest in meadows at intermediate depths (Table II). In some shallow areas shoots of Posidonia are scarce and dead rhizome, overgrown by photophilic algae, dominate. There are also some meadows that develop in the steep channel slopes of the central basin, where shoot density is patchy and usually very low.

Three kinds of Cymodocea nodosa meadows can also be distinguished depending on their dominant

Table II. Average above-ground biomass, epiphyte biomass, and shoot density at different depths, in the Posidonia oceanica meadows from Addaia Bay in summer.

\begin{tabular}{lllll}
\hline Posidonia oceanica & $0.5 \mathrm{~m}$ & $2.5 \mathrm{~m}$ & $4.5 \mathrm{~m}$ & $9.5 \mathrm{~m}$ \\
\hline $\begin{array}{l}\text { Leaves and sheaths } \\
\left.\quad(\mathrm{g} \mathrm{dw} \mathrm{m})^{-2}\right)\end{array}$ & 674 & 1205 & 607 & 337 \\
$\begin{array}{l}\text { Epiphytes }(\mathrm{g} \mathrm{dw} \mathrm{m} \\
\text { Shoots } \mathrm{m}^{-2}\end{array}$ & 315 & 164 & 272 & 80 \\
Sho & 606 & 952 & 531 & 235 \\
\hline
\end{tabular}

Data estimated from measures in 20 quadrats of $20 \mathrm{~cm}$ $\times 20 \mathrm{~cm}$ species composition. Pure Cymodocea stands have the highest density and biomass (Table III). Cymodocea nodosa coexists with Zostera noltii in some parts of the inner part of the central basin and Zostera even can be the dominant species in some areas. However, there are no pure Zostera beds in Addaia. Shoot density and biomass of these species in these mixed meadows are highly variable (Table III). Cymodocea nodosa can also constitute mixed meadows with Caulerpa prolifera that can be considered as a transition between Cymodocea stands from very shallow waters and the muddy bottoms with $\mathrm{Cau}$ lerpa prolifera thriving in relatively deep waters; density and biomass of Cymodocea is usually high (Table III). Other species that are occasionally abundant in these Cymodocea meadows are the green algae Halimeda tuna, Valonia aegagropila and Chaetomorpha linum, and the red algae Rytiphloea tinctoria, Lithothamnion corallioides and Alsidium corallinum (Table IV).

Although the distribution of Ruppia cirrhosa is very reduced (Fig. 3), the meadow is well delimited and has a very high shoot density. The total biomass of the community amounts to $280 \mathrm{~g} \mathrm{dw} \mathrm{m}^{-2}$ (Table IV). Some shoots of Cymodocea nodosa can also be present. Cladophora liniformis was abundant in September 1995 (Table IV) but Chaetomorpha linum and blue green algae bloomed in August 1996 completely removing the above-ground biomass of Ruppia cirrhosa.

Density and biomass of Caulerpa prolifera in the communities dominated by this species is very variable since there are all the possible situations from dense stands thriving in compact sediments to muddy bottoms almost devoid of Caulerpa. Species composition and abundances of dense stands are given in Table IV. Caulerpa prolifera is always the dominant species although the seagrass Zostera noltii and Cymodocea nodosa are usually present. Other abundant macroalgae are Cystoseira ercegovicii, Cladophora vagabunda and Cladophora rupestris.

Table III. Minimal, maximal and average shoot biomass, rhizome biomass, root biomass, and shoot densities for stands of Ruppia cirrhosa, Cymodocea nodosa and Zostera noltii from Addaia Bay.

\begin{tabular}{|c|c|c|c|c|c|c|}
\hline & $\begin{array}{l}\text { Ruppia cirrhosa } \\
\mathrm{n}=2\end{array}$ & $\begin{array}{l}\text { Cymodocea } \\
\text { nodosa pure } \\
\mathrm{n}=8\end{array}$ & $\begin{array}{l}\text { Cymodocea } \\
\text { nodosa with } \\
\text { Zostera } \\
\mathrm{n}=4\end{array}$ & $\begin{array}{l}\text { Cymodocea } \\
\text { nodosa with } \\
\text { Caulerpa } \\
\mathrm{n}=3\end{array}$ & $\begin{array}{l}\text { Zoster } \\
\text { with } C \\
\mathrm{n}=3\end{array}$ & $\begin{array}{l}\text { a noltii } \\
\text { ymodocea }\end{array}$ \\
\hline $\begin{array}{l}\text { Leaves and sheaths } \\
\qquad\left(\mathrm{g} \mathrm{dw} \mathrm{m}^{-2}\right)\end{array}$ & $106-185(146)$ & $95-240(133)$ & $13-90(49)$ & $27-109(75)$ & $18-$ & $54(31)$ \\
\hline $\begin{array}{l}\text { Rhizomes } \\
\qquad\left(g_{d w ~ m}{ }^{-2}\right)\end{array}$ & $59-105(82)$ & $99-397(219)$ & $18-223(146)$ & $148-223(182)$ & $15-$ & $44(32)$ \\
\hline $\begin{array}{l}\text { Roots } \\
\qquad\left(\mathrm{g} \mathrm{dw} \mathrm{m}^{-2}\right)\end{array}$ & $16-24(20)$ & $59-349(154)$ & $6-60(33)$ & $9-\quad 59(42)$ & $6-$ & $31(19)$ \\
\hline Shoots $\mathrm{m}^{-2}$ & 9425 & $1000-2325(1656)$ & $75-750(394)$ & $200-1550(833)$ & \multicolumn{2}{|c|}{$200-1600(875)$} \\
\hline
\end{tabular}

$\mathrm{n}=$ number of samples collected. 
Table IV. Species composition and average biomass $\left(\mathrm{g} \mathrm{dw} \mathrm{m}^{-2}\right)$ for Ruppia cirrhosa, Cymodocea nodosa and Caulerpa prolifera meadows, and macroalgal stands on rocky substrata or dead rhizome of Posidonia oceanica dominated by Cystoseira spp. or Padina pavonica.

\begin{tabular}{|c|c|c|c|c|c|}
\hline & $\begin{array}{l}\text { Ruppia } \\
\mathrm{n}=2\end{array}$ & $\begin{array}{l}\text { Cymodocea } \\
\mathrm{n}=14\end{array}$ & $\begin{array}{l}\text { Caulerpa } \\
\mathrm{n}=3\end{array}$ & $\begin{array}{l}\text { Cystoseira } \\
\mathrm{n}=7\end{array}$ & $\begin{array}{l}\text { Padina } \\
\mathrm{n}=2\end{array}$ \\
\hline Alsidium corallinum C. Agardh & - & 1.53 & 1.44 & 1.79 & - \\
\hline Alsidium helminthochorton (La Tourette) Kützing & - & - & - & 20.30 & - \\
\hline Amphiroa rigida Lamouroux & - & - & - & - & 9.03 \\
\hline Anadyomene stellata (Wulfen) C. Agardh & - & - & - & 1.64 & 0.81 \\
\hline Caulerpa prolifera (Forsskål) Lamouroux & - & 6.68 & 147.84 & 9.78 & - \\
\hline Cladophora echinus (Biasoletto) Kützing & - & - & 0.80 & - & - \\
\hline Cladophora liniformis Kützing & 15.80 & - & - & - & - \\
\hline Cladophora nigrescens Zanardini ex Frauenfeld & - & - & - & 1.99 & - \\
\hline Cladophora prolifera (Roth) Kützing & - & - & - & 0.51 & - \\
\hline Cladophora retroflexa (Bonnemaison) Crouan & - & 0.13 & - & - & - \\
\hline Cladophora rupestris (L.) Kützing & - & 1.02 & 4.20 & - & - \\
\hline Cladophora vagabunda (L.) Hoek & - & - & 5.24 & - & - \\
\hline Cladophora sp. & - & - & - & 0.04 & - \\
\hline Cladophoropsis monodensis (Kützing) Reinbold & - & 0.27 & - & - & - \\
\hline Corallina granifera Ellis et Solander & - & 0.36 & - & 305.05 & 0.71 \\
\hline Cryptonemia lomation (Bertoloni) J. Agardh & - & - & - & 0.02 & - \\
\hline Cymodocea nodosa (Ucria) Ascherson & 16.89 & 420.95 & 12.01 & - & - \\
\hline $\begin{array}{l}\text { Cystoseira compressa (Esper) Gerloff et } \\
\text { Nizamuddin v. pustulata Ercegovic }\end{array}$ & - & - & - & 30.88 & 24.17 \\
\hline Cystoseira crinita (Desfontaines) Bory ex Montagne & - & - & - & 948.50 & - \\
\hline Cystoseira ercegovicii Giaccone & - & 0.53 & 6.62 & 119.25 & - \\
\hline Cystoseira sp. & - & 0.95 & - & 72.77 & - \\
\hline Chaetomorpha linum (O. F. Müller) Kützing & - & 2.88 & - & - & - \\
\hline Dasycladus vermicularis (Scopoli) Krasser & - & - & - & 10.35 & 8.58 \\
\hline Delesseriaceae unidentified & - & - & - & 0.12 & - \\
\hline Dictyopteris membranacea (Stackhouse) Batters & - & - & - & 0.11 & - \\
\hline Dictyota linearis (C. Agardh) Greville & - & 0.05 & - & 3.08 & 1.06 \\
\hline Dictyotaceae unidentified & - & - & 0.01 & 0.48 & 0.29 \\
\hline Dictyota fasciola (Roth) Lamouroux & - & - & - & 4.72 & - \\
\hline Flabellia petiolata (Turra) Nizamuddin & - & 0.32 & - & 1.35 & - \\
\hline Halimeda tuna (Ellis et Solander) Lamouroux & - & 9.43 & - & 4.37 & 38.18 \\
\hline Halopteris filicina (Grateloup) Kützing & - & - & - & 0.24 & - \\
\hline Halopteris scoparia (L.) Sauvageau & - & 0.03 & - & 13.59 & 26.75 \\
\hline Laurencia gr. obtusa (Hudson) Lamouroux & - & 0.57 & 0.05 & 6.93 & - \\
\hline Laurencia sp. & - & 0.33 & 0.19 & 0.01 & - \\
\hline Lithothamnion corallioides Crouan et Crouan & - & 8.44 & - & - & - \\
\hline Lobophora variegata (Lamouroux) Womersley & - & - & - & 4.53 & - \\
\hline Lophosiphonia reptabunda (Suhr) Kylin & - & 0.02 & - & 8.50 & - \\
\hline Nitophyllum punctatum (Stackhouse) Greville & - & - & - & 0.01 & - \\
\hline Padina pavonica (L.) Thivy & - & - & - & 9.19 & 208.01 \\
\hline Penicillus capitatus Lamarck & - & - & - & 1.13 & - \\
\hline Polysiphonia furcellata (C. Agardh) Harvey & - & - & - & 0.34 & - \\
\hline Polysiphonia subulifera (C. Agardh) Harvey & - & 0.12 & - & 0.25 & 0.20 \\
\hline Pseudolithoderma adriaticum (Hauck) Verlaque & - & - & - & 5.36 & - \\
\hline Rhodymenia ardissonei J. Feldmann & - & - & - & 0.03 & - \\
\hline Unidentified encrusting Rhodophyta & - & - & - & 0.75 & 3.50 \\
\hline Ruppia cirrhosa (Petagna) Grande & 247.34 & - & - & - & - \\
\hline Rytiphloea tinctoria (Clemente) C. Agardh & - & 32.23 & 0.19 & 0.10 & - \\
\hline Sargassum vulgare C. Agardh & - & - & - & - & 1.33 \\
\hline Spermothamnion flabellatum Bornet & - & - & - & 0.05 & - \\
\hline Sphacelaria cirrosa (Roth) C. Agardh & - & - & - & 15.55 & - \\
\hline Spongites notarisii (Dufour) Athanasiadis & - & - & - & 502.39 & 605.94 \\
\hline Symploca hydnoides Kützing & - & 0.20 & - & 0.23 & - \\
\hline Valonia aegagropila J. Agardh & - & 9.95 & - & 8.27 & - \\
\hline Valonia utricularis (Roth) C. Agardh & - & - & - & 0.12 & - \\
\hline Zanardinia prototypus (Nardo) Nardo & - & - & & 2.06 & - \\
\hline Zostera noltii Hornemann & - & 13.58 & 20.61 & - & - \\
\hline Seagrass biomass & 264.23 & 434.53 & 32.63 & - & - \\
\hline Algal biomass & 15.80 & $\begin{array}{r}76.04 \\
510.57\end{array}$ & $\begin{array}{l}166.59 \\
199.22\end{array}$ & $\begin{array}{l}2116.74 \\
2116.74\end{array}$ & $\begin{array}{l}928.54 \\
928.54\end{array}$ \\
\hline Total biomass & 280.03 & & & & \\
\hline
\end{tabular}

$\mathrm{n}=$ number of samples collected. 
The rocky coastline and the scattered rocky bottoms are covered by photophilic algal communities. Cystoseira species (mainly Cystoseira crinita and Cystoseira ercegovicii) and the epiphyte Corallina granifera dominate at shallow depths $(0-1 \mathrm{~m})$, while Padina pavonica dominates in deeper areas. The encrusting coralline Spongites notarisii is always the dominant species in the basal stratum (Table IV). Species richness is high and the average algal biomass ranges from $2120 \mathrm{~g} \mathrm{dw} \mathrm{m}^{-2}$ for Cystoseira-dominated communities to $930 \mathrm{~g} \mathrm{dw} \mathrm{m}^{-2}$ for Padina-dominated communities (Table IV).

Macrophyte cover in sandy and muddy bottoms is restricted to scattered shoots of seagrasses (Cymodocea, Zostera) and some fronds of Caulerpa. Blue green algal beds in the eastern basin lagoon are mainly made up of filamentous species, with no macroalgae or seagrasses present.

\section{Discussion}

Cartography of shallow, highly patchy, benthic communities is a rather difficult and long task. Subsequently, detailed bionomic charts of coastal areas are very scarce in the Mediterranean. They are usually restricted to marine reserves or national parks such as Port-Cros (Augier and Boudouresque 1970, 1976), Medes islands (Gili and Ros 1985), Nueva Tabarca (Ramos 1985), Columbretes islands (García Carrascosa 1987) or Elbu Bay (Meinesz et al. 1988), coastal lagoons (Pérez-Ruzafa et al. 1989), harbours (Pergent et al. 1991), or noteworthy underwater biogenic structures (Boudouresque et al. 1985). Addaia Bay is an excellent example of an enclosed bay with a broad representation of the major benthic Mediterranean communities thriving in sheltered shallow areas. Cymodocea nodosa is restricted to sedimentary bottoms from sheltered areas not occupied by Posidonia oceanica, which prefers open areas. Cymodocea nodosa beds also colonize dead rhizomes of Posidonia oceanica in the shallow lagoon at the inner part of the eastern basin and in the margins of the central basin, in agreement with the hypothesis of the Posidonia barrier reef formation (Pérès and Picard 1964), and in accordance with Posidonia and Cymodocea ecological requirements (den Hartog 1970). Zostera noltii is always mixed with Cymodocea nodosa in very shallow areas and never forms pure stands, as has been found in other Mediterranean bays and lagoons (e. g. Molinier and Picard 1953, Hoek 1960, Augier and Boudouresque 1970, Pérez and Camp 1986). Ruppia cirrhosa meadows are restricted to the most sheltered areas where fluctuations in temperature and salinity may be higher, also in accordance with its eurybiontic attributes (Verhoeven 1979). Finally, Caulerpa prolifera preferentially develops in muddy areas with low Cymodocea and Zostera coverage, as indicated by Meinesz (1972).
The existence of a well-developed Posidonia oceanica barrier reef is noteworthy, since most of these formations have disappeared or are in clear regression all over the Mediterranean due to pollution, dredging or other anthropic disturbances (Augier and Boudouresque 1970; Boudouresque et al. 1975, 1980, 1985). The structure of the reef and the adjacent lagoon is similar to the structure described for the Port-Cros formation (Augier and Boudouresque 1970). However, some differences can be pointed out. The lagoon is very extense and shallow, with a maximum depth above $1 \mathrm{~m}$, and it is covered by a luxuriant meadow of Cymodocea nodosa. The absence of silty sediments, even in the shallowest parts, probably accounts for the lack of a Zostera noltii meadow at the inner part of the lagoon, since this species preferably thrives on silt and mud (Pérès and Picard 1964). The lack of freshwater inputs into the lagoon also prevents the development of Zostera noltii, since the speed and rate of success of germination are increased by periods of low salinity (Hootsmans et al. 1987, Loques et al. 1990). There is a great development of benthopleustophytes (mainly Valonia aegagrophila, $R y$ tiphloea tinctoria and Lithothamnion corallioides) which lie below the leaves of Cymodocea nodosa. Similar populations are also found in other parts of the central basin of Addaia, always on Cymodocea bottoms with sand or gravel, as previously described from lagoons and coastal valleys from Italy (Calvo et al. 1982, Giaccone et al. 1994).

Shoot densities of Posidonia oceanica recorded in Addaia (Table II) are similar to those recorded in Medes Islands or Port-Cros (Romero 1989, PergentMartini and Pergent 1994), but rather low when compared to other meadows (Pergent-Martini and Pergent 1994). Epiphyte biomass is also similar or higher than other values reported in the literature (Thelin and Bédhomme 1983, Mazzella and Ott 1984, Ballesteros 1987, Romero 1988). Living root and rhizome biomass, although not measured in our samples, can be roughly estimated as $3050 \mathrm{~g} \mathrm{dw} \mathrm{m}^{-2}$, taking into account the average below-ground biomass of shallow (above $13 \mathrm{~m}$ ) Posidonia oceanica meadows measured in Ischia (Romero et al. 1992) and Medes Islands (Mateo 1995). Shoot densities (1000-1900 shoots $\mathrm{m}^{-2}$ ) and biomass (up to $170 \mathrm{~g} \mathrm{dw} \mathrm{m}^{-2}$ ) of Cymodocea nodosa are also in the ranges reported from other meadows (Pérez and Camp 1986, Peduzzi and Vukovic 1990, Terrados and Ros 1992, Reyes et al. 1995). On the contrary, Zostera noltii densities (200-1600 shoots $\mathrm{m}^{-2}$ ) are lower than those reported by other authors (Pérez and Camp 1986, Vermaat et al. 1987, Lent et al. 1991, Vermaat et al. 1993, Pérez-Llorens and Niell 1993), probably because Zostera always constitutes mixed meadows with Cymodocea in Addaia. Although seasonal and interannual variations in biomass of Ruppia cirrhosa are very important, our biomass measures from September 1994 in Addaia, are higher than those found in northern 
Table V. Estimates of total plant (seagrass and algal) biomass of the different phytobenthic communities from an areal basis $\left(\mathrm{g} \mathrm{dw} \mathrm{m}^{-2}\right)$ and for the whole Addaia Bay $(\mathrm{t} \mathrm{dw})$, considering the area occupied by each community. Area occupied by the communities Posidonia/dead rhizome and $C y$ modocea/boulders (see Table I) have been considered to estimate the total area covered by Cymodocea nodosa, Posidonia oceanica and Dead Rhizome.

\begin{tabular}{|c|c|c|c|}
\hline Community & $\begin{array}{l}\text { Surface } \\
\text { (ha) }\end{array}$ & $\begin{array}{l}\text { Biomass } \\
\left(\mathrm{gdw} \mathrm{m}^{-2}\right)\end{array}$ & $\begin{array}{l}\text { Total } \\
\text { Biomass } \\
(\mathrm{t} \mathrm{dw})\end{array}$ \\
\hline Cymodocea & 37,08 & 511 & 189.3 \\
\hline Posidonia $0-4 \mathrm{~m}$ & 14,95 & 4231 & 632.5 \\
\hline Posidonia 4-12 m & 9,04 & 3700 & 334.5 \\
\hline Caulerpa & 8,7 & 199 & 17.3 \\
\hline Dead rhizome & 3,93 & 929 & 36.5 \\
\hline Photophilic Algae & 0,58 & 2117 & 12.3 \\
\hline Ruppia & 0,24 & 280 & 0.7 \\
\hline Tota & & & 1223.1 \\
\hline
\end{tabular}

Europe (Verhoeven 1980), and similar to other data reported from shallow bays and lagoons, also in September, in the Ebro Delta (Spain) (Pérez 1989, Menéndez and Comín 1989). Biomass of Caulerpa prolifera $\left(90-190 \mathrm{~g} \mathrm{dw} \mathrm{m}^{-2}\right)$ is also similar to biomass from other Mediterranean meadows of this species (Meinesz 1979, Ballester 1985, Ballesteros 1990, Terrados and Ros 1995). Finally, the biomass of photophilic algae, collected from rocky substrata or dead seagrass rhizome, is consistent with values obtained by Ballesteros (1992).

Pollution, unbalanced sediment budgets, and eroding processes (anchoring, digging, trawl fishing) cause the disappearance of Posidonia oceanica meadows (Meinesz and Lefevre 1978, Pérès 1984), and the substitution of Cymodocea nodosa meadows by muddy bottoms, sometimes covered by Caulerpa prolifera or by highly seasonal, abnormal developments of Ulvales, Cladophorales, Gracilaria, and other ubiquitous algae (Cecere et al. 1991, Giaccone 1993, Sfriso et al. 1993, Morand and Briand 1996). Dredging, trampling and pollution cause the regression of Posidonia oceanica reefs (Boudouresque et al. 1975). On shallow rocky areas affected by pollution or overfishing, the Cystoseira-dominated communities are substituted by communities dominated by Dictyotales and Corallinales (Ballesteros et al. 1984, Verlaque 1987, Hoffmann et al. 1988, Boudouresque et al. 1990, Giaccone 1993). Thus, according to the composition and extension of its phytobenthic communities, it can be stated that Addaia Bay is in a rather healthy condition. The only important anthropic disturbance seems to be the marina construction and the dredging of the marina and of the central channel of the main basin, which probably accounted for the die-off of all the vegetation from this area and the spreading of the muddy bottoms devoid of macrophytes.

Considering the biomass values and the surfaces occupied by each community, the total phytobenthic standing crop of Addaia Bay in summer (August) can be estimated as $1220 \mathrm{t} \mathrm{dw}$ (491 $\mathrm{t}$ if below-ground biomass of Posidonia oceanica is not considered) (Table V). Posidonia oceanica meadows account for most of the standing crop of the bay (79\%), even if belowground biomass is not considered (48\%). Seagrasses account for nearly the $95 \%$ of the total biomass. A rough estimate of benthic primary production can be obtained from the summer biomass values of the main species, the area occupied by each species, and the productivity data obtained from the literature (Table VI). The figure of $459 \mathrm{tdw} \mathrm{y}^{-1}$ for the whole

Table VI. Estimates of primary production (per $\mathrm{m}^{2}$ and total) of each species or groups of species from the different phytobenthic communities distinguished in Addaia Bay, considering productivity data from the literature, summer biomass of the different species (see tables II to IV), and area occupied by each species or groups of species. Differences on the productivity of leaves, rhizomes, and roots have been taken into account to estimate seagrass production.

\begin{tabular}{llrlll}
\hline Species & Community & Surface & $\begin{array}{l}\text { Pro- } \\
\text { duction } \\
(\mathrm{g} \mathrm{dw} \\
\left.\mathrm{m}^{-2} \mathrm{y}^{-1}\right)\end{array}$ & $\begin{array}{l}\text { Total } \\
\text { Production } \\
\left(\mathrm{t} \mathrm{dw} \mathrm{y} \mathrm{d}^{-1}\right)\end{array}$ & P and P/B data references \\
\hline Cymodocea nodosa & Cymodocea & 37.08 & 286 & 106.1 & Pérez (1989), Terrados and Ros (1992) \\
Photophilic Algae & Cymodocea & 37.08 & 76 & 28.2 & Ballesteros (1992) \\
Zostera noltii & Cymodocea & 37.08 & 31 & 11.5 & Pérez (1989) \\
Posidonia oceanica & Posidonia 0-4 m & 14.95 & 870 & 130.1 & Pergent-Martini et al. (1994) \\
Posidonia oceanica & Posidonia 4-12 m & 9.04 & 470 & 42.5 & Pergent-Martini et al. (1994) \\
Epiphytes & Posidonia 0-12 m & 23.99 & 240 & 57.6 & Romero (1988), Ballesteros (1987) \\
Caulerpa prolifera & Caulerpa & 8.70 & 270 & 23.5 & Meinesz (1979) \\
Photophilic Algae & Dead rhizome & 3.93 & 1000. & 39.3 & Ballesteros (1992) \\
Photophilic Algae & Rocky substrate & 0.58 & 1700 & 9.9 & Ballesteros (1989) \\
Ruppia cirrhosa & Ruppia & 0.24 & 475 & 1.1 & Pérez (1989) \\
\hline
\end{tabular}


bay represents an average areal production of $530 \mathrm{~g}$ $\mathrm{dw} \mathrm{m}^{-2} \mathrm{y}^{-1}$, which is rather high when compared to estimates from other Mediterranean bays ( 75 to $230 \mathrm{~g}$ $\mathrm{dw} \mathrm{m} \mathrm{m}^{-2} \mathrm{y}^{-1}$; Pérez 1989) and similar to the roughly $600 \mathrm{~g} \mathrm{dw} \mathrm{m}^{-2-1}$ obtained for the Mar Menor lagoon (Terrados and Ros 1991). These values emphasize the important contribution of benthic primary production to the productivity of Mediterranean coastal areas and the predominant role played by seagrass meadows in these environments.

\section{References}

Augier, H. and C. F. Boudouresque. 1970. Végétation marine de l'île de Port-Cros (Parc National). VI. Le récifbarrière de Posidonies. Bull. Mus. Hist. Nat. Marseille 30: $221-228$.

Augier, H. and C. F. Boudouresque. 1976. Végétation marine de l'île de Port-Cros (Parc National). XIII. Documents pour la carte des peuplements benthiques. Trav. Sci. Parc Nation. Port-Cros 2: 9-22.

Ballester, R. 1985. Biomasa, estacionalidad y distribución de tres macrófitos: Ruppia cirrhosa, Cymodocea nodosa y Caulerpa prolifera en el Mar Menor (Murcia, SE España). Anal. Biol. 4: 31-36.

Ballesteros, E. 1987. Estructura i dinàmica del poblament algal de les fulles de Posidonia oceanica (L.) Delile als herbeis de Tossa de Mar (Girona). Butll. Inst. Cat. Hist. Nat. 54: 13-30.

Ballesteros, E. 1989. Production of seaweeds in northwestern Mediterranean marine communities: its relation with environmental factors. Scient. Mar. 53: 357-364.

Ballesteros, E. 1990. Els herbeis de Caulerpa prolifera (Forsskål) Lamouroux de la badia de Pollença (Mallorca, Mediterrània Occidental). Boll. Soc. Hist. Nat. Balears 33: 99-116.

Ballesteros, E. 1992. Els vegetals i la zonació litoral: espècies, comunitats i factors que influeixen en la seva distribució. Arx. Secc. Cienc. Inst. Est. Cat. 101: 1-613.

Ballesteros, E., M. Pérez and M. Zabala. 1984. Aproximación al conocimiento de las comunidades algales de la zona infralitoral superior en la costa catalana. Collect. Bot. 15: 69-100.

Bay, D. 1984. A field study on the growth dynamics and productivity of Posidonia oceanica (L.) Delile in Calvi Bay, Corsica. Aquat. Bot. 20: 43-64.

Bédhomme, A. L., I. Thélin and C. F. Boudouresque. 1983. Mesure de la production primaire des feuilles de Posidonia oceanica: Modifications de la méthode de Zieman. Bot. Mar. 26: 35-43.

Boudouresque, C. F. 1971. Méthodes d'étude qualitative et quantitative du benthos (en particulier du phytobenthos). Téthys 3(1): 79-104.

Boudouresque, C. F. and A. Meinesz. 1982. Découverte de l'herbier de Posidonie. Cahiers Parc National de PortCros 4: 1-81.

Boudouresque, C. F., H. Augier, T. Belsher, E. Coppejans and M. Perret. 1975. Végétation marine de l'île de PortCros, $\mathrm{X}$. La régression du récif-barrière de Posidonies. Trav. Sci. Parc Nation. Port-Cros 1: 41-46.

\section{Acknowledgements}

This work has been funded by the European Union, MAST II Program, contract MAS2-CT93-0053. Natàlia Sant and Teresa Alcoverro are kindly acknowledged for their field support. Thanks are also due to G. Carreras for drawing Figure 1.

Accepted 6 August 1997

Boudouresque, C. F., G. Giraud and P. Panayotidis. 1980. Végétation marine de l'île de Port-Cros (Parc National), XIX: mise en place d'un transect permanent. Trav. Sci. Parc Nation. Port-Cros 6: 207-221.

Boudouresque, C. F., A. Meinesz and J. R. Lefevre. 1985. Cartographie des peuplements benthiques marins de Corse: I. La formation récifale à Posidonia oceanica de Saint-Florent. Ann. Inst. Océanogr. N. S. 61(1): 27-38.

Boudouresque, C. F., A. Meinesz, E. Ballesteros, N. Ben Maiz, F. Boisset, F. Cinelli, S. Cirik, M. Cormaci, A. Jeudy de Grissac, J. Laborel, E. Lanfranco, B. Lundberg, H. Mayhoub, P. Panayotidis, R. Semroud, J. M. Sinnassamy and A. Span. 1990. Livre Rouge "Gérard Vuignier " des végétaux, peuplements et paysages marins menacés de Méditerranée. MAP Technical Report Series 43. UNEP/IUCN/GIS Posidonie. Athens. 250 pp.

Calvo, S., G. Giaccone and S. Ragonese. 1982. Tipologia della vegetazione sommersa dello stagnone di Marsala (TP). Naturalista Sicil., s. IV, VI (Suppl.) 2: 187-196.

Caye, G. and A. Meinesz. 1985. Observations on the vegetative development, flowering and seedling of Cymodocea nodosa (Ucria) Ascherson on the Mediterranean coasts of France. Aquat. Bot. 22: 277-289.

Cecere, E., M. Cormaci and G. Furnari. 1991. The marine algae of Mar Piccolo, Taranto (Southern Italy): a reassessment. Bot. Mar. 34: 221-227.

Colantoni, P., P. Callignani, E. Fresi and F. Cinelli. 1982. Patterns of Posidonia oceanica (L.) Delile beds around the island of Ischia (Gulf of Naples) and adjacent waters. P. S. Z. N. I.: Mar. Ecol. 3: 53-74.

García Carrascosa, A. M. 1987. El bentos de los alrededores de las islas Columbretes. Elementos para su cartografía bionómica. In: (L. A. Alonso, J. L. Carretero and A. M. García Carrascosa, eds) Islas Columbretes. Contribución al estudio de su medio natural: Generalitat Valenciana. Valencia. pp. 477-495.

Giaccone, G. 1993. The vertical zonation along the phytal system in the Mediterranean Sea and effects of municipal and industrial wastewater disposal on phytobenthos communities. Proceed. 5th Optima Meeting: 47-56.

Giaccone, G., G. Alongi, F. Pizzuto and A. Cossu. 1994. La vegetazione marina bentonica fotofila del Mediteraneo: II. Infralitorale e circalitorale. Proposte di aggiornamento. Boll. Acc. Gioenia Sci. Nat. 27: 111-157.

Gili, J. and J. D. Ros. 1985. Study and cartography of the benthic communities of Medes islands (NE Spain). P. S. Z. N. I.: Mar. Ecol. 6: 219-238. 
Giraud, G. 1977. Essai de classement des herbiers de Posidonia oceanica (L.) Delile. Bot. Mar. 20: 487-491.

Hartog, C. den. 1970. The Seagrasses of the World. North Holland Publ. Co., Amsterdam. 275 pp.

Hoek, C. Van den. 1960. Groupements d'algues des étangs saumâtres méditerranéens de la côte française. Vie Milieu 11: 340-412.

Hoffmann, L., S. Clarisse, X. Detienne, A. Goffart, R. Renard and V. Demoulin. 1988. Evolution of the populations of Cystoseira balearica (Phaeophyceae) and epiphytic Bangiophyceae in the Bay of Calvi (Corsica) in the last eight years. Bull. Soc. Roy. Liège 57: 263-273.

Hootsmans, M. J. M., J. E. Vermaat and W. Van Vierssen. 1987. Seed-bank development, germination and early seeding survival of two seagrass species from the Netherlands: Zostera marina L. and Zostera noltii Hornem. Aquat. Bot. 28: 275-285.

Lent, F. van, P. H. Nienhuis and J. M. Verschuure. 1991. Production and biomass of the seagrasses Zostera noltii Hornem. and Cymodocea nodosa (Ucria) Aschers. at the Banc d'Arguin (Mauritania, NW Africa): a preliminary approach. Aquat. Bot. 41: 353-367.

Loques, F., G. Caye and A. Meinesz. 1990. Germination in the marine phanerogam Zostera noltii Hornemann at Golfe Juan, French Mediterranean. Aquat. Bot. 38: 249-260.

Marbà, N., J. Cebrián, S. Enríquez and C. M. Duarte. 1996. Growth patterns of Western Mediterranean seagrasses: species-specific responses to seasonal forcing. Mar. Ecol. Progr: Ser: 133: 203-215.

Mateo, M. A. 1995. El compartimento detrítico en ecosistemas de fanerógamas marinas mediterráneas. Tesis Doctoral. Universidad de Barcelona. 214 pp.

Mazzella, L. and J. A. Ott. 1984. Seasonal changes in some features of Posidonia oceanica (L.) Delile leaves and epiphytes at different depths. In: (C. F. Boudouresque, A. Jeudy de Grissac and J. Olivier, eds) First International Workshop on Posidonia oceanica Beds. GIS Posidonie, Marseille. pp. 119-127.

Meinesz, A. 1972. Répartition de Caulerpa prolifera (Forsskål) Lamouroux sur les côtes continentales françaises de la Méditerranée. Téthys 4: 843858.

Meinesz, A. 1979. Contribution à l'étude de Caulerpa prolifera (Forsskål) Lamouroux (Chlorophycée, Caulerpales). III - Biomasse et productivité primaire dans une station des côtes continentales françaises de la Méditerranée. Bot. Mar. 22: 123-127.

Meinesz, A. and J. R. Lèfevre. 1978. Destruction de l'étage infralittoral des Alpes-Maritimes (France) et de Monaco par les restructurations du rivage. Bull. Ecol. 9: 259276.

Meinesz, A., C. F. Boudouresque and J. R. Lefevre. 1988. A map of the Posidonia oceanica beds of Marina d'Elbu (Corsica, Mediterranean). P.S.Z. N. I.: Mar. Ecol. 9: 243-252.

Meinesz, A., M. Cuvelier and R. Laurent. 1981. Méthodes récentes de cartographie et de surveillance des herbiers de phanérogames marines. Leurs applications sur les côtes françaises de la Méditerrancée. Vie Milieu 31: 27-34.

Menéndez, M. and F. A. Comín. 1989. Seasonal patterns of biomass variation of Ruppia cirrhosa (Petagna) Grande and Potamogeton pectinatus L. in a coastal lagoon. Scient. Mar. 53: 633-638.

Molinier, R. and J. Picard. 1952. Recherches sur les herbiers de phanérogames marines du littoral méditerranéen français. Ann. Inst. Océanogr: 27: 157-234.

Molinier, R. and J. Picard. 1953. Études biologiques sur les herbiers de phanérogames marines à l'ouest d'Alger. Stat. Aquicult. Pêche Castiglione, N. S. 4: 335-362.

Morand, P. and X. Briand. 1996. Excessive growth of macroalgae: a symptom of environmental disturbance. Bot. Mar: 39: 491-516.

Peduzzi, P. and A. Vukovic. 1990. Primary production of Cymodocea nodosa in the Gulf of Trieste (Northern Adriatic Sea): a comparison of methods. Mar. Ecol. Progr. Ser. 64: 197-207.

Pérès, J. M. 1984. La régression des herbiers à Posidonia oceanica. In: (C. F. Boudouresque, A. Jeudy de Grissac and J. Olivier, eds) First International Workshop on Posidonia oceanica Beds. GIS Posidonie, Marseille. pp. 445-454.

Pérès, J. M. and J. Picard. 1964. Nouveau manuel de bionomie benthique de la Mer Méditerranée. Rec. Trav. St. Mar. Endoume 31(47): 5-137.

Pérez, M. 1989. Fanerógamas marinas en sistemas estuáricos: producción, factores limitantes y algunos aspectos del ciclo de nutrients. Tesis doctoral. Universidad de Barcelona. $244 \mathrm{pp}$.

Pérez, M. and J. Camp. 1986. Distribución espacial y biomasa de las fanerógamas marinas del Delta del Ebro. Inv. Pesq. 50: 519-530.

Pérez, M. and J. Romero. 1991. Photosynthetic response to light of seagrass Cymodocea nodosa and the prediction of its seasonality. Aquat. Bot. 43: 51-62.

Pérez-Llorens, J. L. and F. X. Niell. 1993. Seasonal dynamics of biomass and nutrient content in the intertidal seagrass Zostera noltii Hornem. from Palmones River estuary, Spain. Aquat. Bot. 46: 49-66.

Pérez-Ruzafa, A., J. Ros, C. Marcos, R. Ballester and I. M. Pérez-Ruzafa. 1989. Distribution and biomass of the macrophyte beds in a hypersaline coastal lagoon (the Mar Menor, SE Spain), and its recent evolution following major environmental changes. In: (C. F. Boudouresque, A. Meinesz, E. Fresi and V. Gravez, eds) Second International Workshop on Posidonia oceanica Beds. GIS Posidonie, Marseille. pp. 49-62.

Pergent, G., C. F. Boudouresque, I. Thélin, M. Marchadour and C. Pergent-Martini. 1991. Map of benthic vegetation and sea-bottom types in the harbour at Banyuls sur Mer (P. O., France). Vie Milieu 41: 165-168.

Pergent-Martini, C. and G. Pergent. 1994. Lepidochronological analysis in the Mediterranean seagrass Posidonia oceanica: state of the art and future developments. Oceanol. Acta 17: 673-681.

Pergent-Martini, C., V. Rico-Raimondino and G. Pergent. 1994. Primary production of Posidonia oceanica in the Mediterranean basin. Mar. Biol. 120: 9-15.

Ramos, A. 1984. Cartografía de la pradera superficial de Posidonia oceanica en la bahía de Alicante (SE España). In: (C. F. Boudouresque, A. Jeudy de Grissac and J. Olivier, eds) First International Workshop on Posidonia oceanica Beds. GIS Posidonie, Marseille. pp. 57-61. 
Ramos, A. 1985. Contribución al conocimiento de las biocenosis bentónicas litorales de la isla Plana o Nueva Tabarca. In: (A. Ramos, ed.) La reserva marina de la isla Plana o Nueva Tabarca (Alicante). Universidad de Alicante. pp. $111-147$.

Reyes, J., M. Sansón and J. Afonso-Carrillo. 1995. Leaf phenology, growth and production of the seagrass $C y$ modocea nodosa at El Médano (South of Tenerife, Canary Islands). Bot. Mar. 38: 457-465.

Romero, J. 1988. Epífitos de las hojas de Posidonia oceanica: variaciones estacionales y batimétricas de biomasa en la pradera de las islas Medes (Girona). Oecol. Aquat. 9: $19-25$.

Romero, J. 1989. Primary production of Posidonia oceanica beds in the Medas islands (Girona, NE Spain). In: (C. F. Boudouresque, A. Meinesz, E. Fresi and V. Gravez, eds) Second International Workshop on Posidonia oceanica Beds. GIS Posidonie, Marseille. pp. 85-91.

Romero, J., G. Pergent, C. Pergent-Martini, M. A. Mateo and C. Regnier. 1992. The detritic compartment in a Posidonia oceanica meadow: litter features, decomposition rates, and mineral stocks. P. S. Z. N. I.: Mar. Ecol. 13: $69-83$.

Ros, J., J. Romero, E. Ballesteros and J. M. Gili. 1985. Diving in blue water. The benthos. In: (R. Margalef, ed.) Western Mediterranean. Pergamon. Oxford. pp. 233295.

Sfriso, A., A. Marcomini, B. Pavoni and A. A. Orio. 1993. Species composition, biomass and net primary production in shallow coastal waters: the Venice lagoon. Bioresource Technology 44: 235-250.

Terrados, J. and J. Ros. 1991. Production dynamics in a macrophyte-dominated ecosystem: the Mar Menor coastal lagoon (SE Spain). Oecol. Aquat. 10: 255-270.
Terrados, J. and J. Ros. 1992. Growth and primary production of Cymodocea nodosa (Ucria) Ascherson in a Mediterranean coastal lagoon: the Mar Menor (SE Spain). Aquat. Bot. 43: 63-74.

Terrados, J. and J. Ros. 1995. Temporal variation of the biomass and structure of Caulerpa prolifera (Forsskål) Lamouroux meadows in the Mar Menor lagoon (SE Spain). Scient. Mar. 59: 49-56.

Thélin, I. and A. L. Bédhomme. 1983. Biomasse des épiphytes des feuilles de Posidonia oceanica dans un herbier superficiel. Rapp. Comm. int. Mer Médit. 28(3): 125126.

Verhoeven, J. T. A. 1979. The ecology of Ruppia-dominated communities in Western Europe, I. Distribution of Ruppia representatives in relation to their autoecology. Aquat. Bot. 6: 197-268.

Verhoeven, J. T. A. 1980 . The ecology of Ruppia-dominated communities in Western Europe, III. Aspects of production, consumption and decomposition. Aquat. Bot. 8: 209-253.

Verlaque, M. 1987. Contribution à l'étude du phytobenthos d'un écosystème photophile thermophile marin en Méditerranée Occidentale. Thèse. Université Aix Marseille. 389 pp.

Vermaat, J. E., M. J. M. Hootsmans and P. H. Nienhuis. 1987. Seasonal dynamics and leaf growth of Zostera noltii Hornem., a perennial intertidal seagrass. Aquat. Bot. 28: $287-299$.

Vermaat, J. E., J. A. J. Beijer, R. Gijlstra, M. J. M. Hootsmans and C. J. M. Philippart. 1993. Leaf dynamics and standing stocks of intertidal Zostera noltii Hornem. and Cymodocea nodosa (Ucria) Ascherson on the Banc d'Arguin (Mauritania). Hydrobiologia 358: 59-72. 